\title{
Physicochemical and Sensory Properties of Cookies Produced from Wheat, Unripe Plantain and Germinated Fluted Pumpkin Seed Composite Flour
}

\author{
Florence A. Bello ${ }^{1 *} \quad$ Mmenyene E. Akpan ${ }^{1} \quad$ Mopelola A. Sodipo ${ }^{2}$ \\ 1.Department of Food Science and Technology, University of Uyo, Uyo, Nigeria \\ 2.Department of Food Science and Technology, Federal University of Technology, Akure, Nigeria
}

\begin{abstract}
The present study was conducted on preparation and quality evaluation of wheat, unripe plantain and fluted pumpkin seed composite flour cookies. The composite flour prepared from wheat, unripe plantain and germinated pumpkin seed were formulated in the ratio 90:5:5 (A), 85: 5:10 (B), 80:5:15 (C) and 75:5:20 (D) while the 100\% wheat flour (sample E) prepared as control. Functional properties of the composite flour were determined and the quality of cookies produced were evaluated for physicochemical and sensory properties using standard methods. Bulk density, oil absorption capacity and gelatinization temperature of the flour samples decreased significantly $(p<0.05)$ as the level of fluted pumpkin seed flour addition increased. Increase in swelling, water absorption and emulsification capacities were observed and the values were higher than the control. Fortified cookies had similar physical properties with the control in term of thickness, diameter and spread ratio. Crude protein, crude fat, ash and crude fibre of fortified cookies also increased significantly when compared with the control while the carbohydrate content of the fortified cookies had the lowest values. Selected anti-nutrients (HCN, tannin, oxalate and phytate) had values higher than the control except saponin content of samples B, C and D which was lower than the control. The sensory result showed that sample E (100\% wheat flour cookies) was most preferred followed by sample A based on aroma, appearance, taste and general acceptability. The addition of germinated pumpkin seed flour above 5\% has significant negative effect on the acceptance of the cookies.
\end{abstract}

Keywords: Cookies, enriched, nutrition, protein-rich, germinated, pumpkin seed, composite flour

DOI: $10.7176 / \mathrm{FSQM} / 96-05$

Publication date: April $30^{\text {th }} 2020$

\section{Introduction}

Cookies are convenient baked products, ready-to-eat and easily available in different shapes and sizes at an affordable cost with high nutritive value (Vijerathna et al., 2019). They are the most popular bakery items consumed among all age groups in many countries because they have a very acceptable taste and their low water activity allows a long shelf life (Chauhan et al., 2015; Usman et al., 2015). In Nigeria, reliance on wheat flour in the pastry and bakery industries has over the years restricted the use of other cereals and tuber crops available to domestic use. Recently, government has collaborated with the research institutes to encourage the use of composite flours in the production of food products such as cookies, bread etc. Several studies have reported the use of composite flour in cookies production (Akusu et al., 2019; Obinna-Echem and Robinson, 2019; Ukeyima et al., 2019; Bello et al., 2020; Wabali et al., 2020). All these efforts were aimed at improving the nutritional values of the cookies and also to enhance crop utilization.

Wheat (Triticum aestivum) is a common cereal in the world which plays an important role as global commodity due to its gluten forming proteins, which are capable of having extensibility and elasticity required for bakery products and pasta (FAO, 2013; Inyang et al., 2018). Wheat contains $78.10 \%$ carbohydrate, $14.70 \%$ protein, $2.10 \%$ fat, $2.10 \%$ minerals and considerable proportions of vitamins (thiamine and vitamin-B) and minerals (Topping, 2007).

Plantain (Musa paradisiaca) is an important staple food in Central and West Africa (Makanjuola et al., 2013). Plantains are abundant in Nigeria and other developing countries. Plantain fruit is composed of $75 \%$ different elements and $32 \%$ of carbohydrates and it also contains several vitamins including A, B, C and is very low in protein and fat but rich in minerals particularly iron. Also, it is free from cholesterol, high in fibre and low in sodium (Adewole and Duruji, 2010). Because plantains have poor amino acid profile, it should be supplemented with protein rich food crops like legumes. The resulting products would be rich in both protein and carbohydrates.

Fluted pumpkin (Telfairia occidentalis) is a tropical plant. It is widely planted in wet part of Nigeria and West Africa in general and belongs to the family cucurbitaceae (Ehiagbonare, 2008). Fluted pumpkin is grown as a vegetable and for its edible seeds. Nutritionally, fluted pumpkin seed is a good source of protein and it is widely use in the world as foods. However, the seeds contain many kinds of anti-nutritional factors such as phytates, tannins, lectin, saponin and trypsin inhibitors (Bello et al., 2018). Some of these anti-nutritional factors are inactivated during washing, parboiling, spouting, fermenting and soaking while lectins and trypsin inhibitor are inactivated by subjecting it to high temperature and prolonged cooking due to it resistibility (Kuku et al., 2014). 
Composite flour as a mixture of flours, starches, pulse, legumes and other ingredients intended to replace wheat flour totally or partially in bakery and pastry products. The use of composite flours had advantages of reducing high cost on importation and encourages the use of our locally grown crops as flour crop in supplementation of protein for human (Hugo et al., 2000; Hasmadi et al., 2014). Legume proteins can be successfully used in baked products to obtain a protein fortified products with improved amino acid balance (Bojňanská et al., 2012; Mohammed et al., 2012). The objective of the study was therefore to evaluate the functional, physical, proximate, anti-nutrients and sensory properties of wheat, unripe plantain and germinated fluted pumpkin seed composite flour cookies.

\section{Materials and Methods}

\subsection{Materials procurement}

Wheat grains was purchased from Itam market, Uyo, plantain was purchased from National market in Ikot Ekpene and pumpkin seed were purchased from Ikot Mbang market in Uyo metropolis, Akwa Ibom State, Nigeria. Ingredients used for cookies production (margarine, egg, vanilla essence, baking powder and sugar) were purchased from Etuk market in Uyo metropolis. All chemicals used for the analysis were of analar grade.

\subsection{Material preparation}

\subsubsection{Preparation of wheat flour}

One (1) kg of wheat grains was weighed, sorted, washed and oven dried (model NAAFCO BS Oven: OVH-102) at $60{ }^{\circ} \mathrm{C}$ for $20 \mathrm{~h}$. The dried wheat grain was milled in hammer mill, sieved through 150 um wire mesh and packaged in air tight plastic container, labelled and store in a refrigerator (model-AM- 200, Nexus Haier Thermocool, China) at a temperature of $4{ }^{\circ} \mathrm{C}$ prior to analysis.

\subsubsection{Preparation of unripe plantain flour}

The unripe plantain pulp was processed into flour according to the method described by Ogazi and Adeyemi (1985). The plantain fruits were removed from the bunch, washed with clean water and blanched at $100{ }^{\circ} \mathrm{C}$ for $3 \mathrm{~min}$ using water bath to control enzymatic browning. The fruits were immediately cooled and peeled using a sharp knife. The peeled plantains were sliced at average thickness of $0.5 \mathrm{~mm}$. The sliced plantain were placed on the tray and dried in a cabinet oven at $60{ }^{\circ} \mathrm{C}$ for $12 \mathrm{~h}$. It was milled using hammer mill (model Corona) and sieved through a mesh of 500 um pore size sieve to obtain the fine flour. The flour was packaged in air tight plastic container, labelled and store in a refrigerator at a temperature of $4{ }^{\circ} \mathrm{C}$ prior to analysis.

\subsubsection{Preparation of germinated fluted pumpkin seed flour}

The fluted pumpkin seeds were extracted from the fruits. The extracted seeds were arranged on bag layers and wetted daily for 6 days for germination. Germinated seeds were picked, dehulled, cleaned and sliced into small pieces. The seeds were dried in an oven at $60^{\circ} \mathrm{C}$ for $12 \mathrm{~h}$. The dried seeds were ground using commercial blender (Model Philips HR 7762-90, China) and sieved through $500 \mu \mathrm{m}$ and stored in an air tight plastic, labelled and stored in a refrigerator at a temperature of $4{ }^{\circ} \mathrm{C}$ prior to analysis.

2.2.4 Formulation of wheat, unripe plantain and germinated pumpkin seed composite flour The formulation of the composite flour for the production of cookies is presented in Table 1.

\begin{tabular}{cccc}
\multicolumn{4}{c}{ Table 1. Sample formulation (\%) for wheat, unripe plar } \\
and fluted pumpkin seed composite flour \\
\hline Sample & $\begin{array}{c}\text { Unripe cooking } \\
\text { banana flour }\end{array}$ & $\begin{array}{c}\text { Breadfruit } \\
\text { seed Flour }\end{array}$ & $\begin{array}{c}\text { Broken } \\
\text { rice flour }\end{array}$ \\
\hline A & 90 & 5 & 5 \\
B & 85 & 5 & 10 \\
C & 80 & 5 & 15 \\
D & 75 & 5 & 20 \\
E & 100 & 0 & 0 \\
\hline
\end{tabular}

\subsubsection{Production of wheat, unripe plantain and germinated pumpkin seed composite flour cookies}

The method described by Arisa et al. (2013) was used in the production of cookies. Sugar (150 g) and margarine $(200 \mathrm{~g})$ were cream together at medium speed until fluffy. Egg $(100 \mathrm{ml})$ were added during mixing and then mixing continued for about $30 \mathrm{~min} .400 \mathrm{~g}$ of sifted flour, $10 \mathrm{~g}$ of baking powder and $20 \mathrm{~g}$ of vanilla essence flavour were slowly added to the mixture and kneaded to form dough. It was then rolled on a flat rolling board sprinkled with flour to a uniform thickness and cut to a uniform diameters. The cut dough was left for 30 min to rest and placed on a greased baking trays and baked in the oven at $180^{\circ} \mathrm{C}$ for $30 \mathrm{~min}$. The baked products were cooled at ambient temperature for $30 \mathrm{~min}$, packaged in high density polyethylene, labelled and stored at room temperature for various determinations. 


\subsection{Analytical methods}

\subsubsection{Determination of functional properties of composite flour}

Bulk density, water absorption capacity, oil absorption capacity and gelatinization temperature were determined using the method described by Onwuka (2005). Swelling index determination was determined using the method of Abbey and Ibeh (1988).

\subsubsection{Physical properties of cookies}

The method described by Jemziya and Mahendran (2017) was used to determine the diameter, weight, and thickness of the cookie while the spread ratio was calculated by dividing the diameter of the cookie with its thickness.

\subsubsection{Proximate composition of cookies}

Moisture, crude protein, crude lipid, ash and crude fibre contents were determined using the method described in AOAC (2005). Total carbohydrate content was determined by difference using the method of Ihekoronye and Ngoddy (1985). This was done by subtracting the total sum of the percentage for moisture, crude protein, crude lipid, ash and crude fibre content from 100. i.e. $\%$ total Carbohydrate $=100-$ (moisture + crude protein + crude lipid + ash + crude fibre)

\subsubsection{Determination of anti-nutritional factors of cookies}

Total oxalate was determined using the method described by Onwuka (2005). The method of Allen et al. (1974) was used for tannin determination. Hydrogen cyanide (HCN) was determined using alkaline filtration method as described by AOAC (2005) while phytic acid was determined using the method described by Wheeler and Ferrel (1971).

\subsubsection{Sensory evaluation of cookies}

Sensory characteristics of the cookies were evaluated by twenty (20) semi trained panelists drawn from the Department of Food Science and Technology, University of Uyo. All the panelists were briefed before the commencement of the evaluation process. Sensory attributes evaluated were aroma, appearance, taste, texture and overall acceptability. The rating were on a nine- point hedonic scale ranging from 9 (like extremely) to 1 (dislike extremely) according to the method of Ihekoronye and Ngoddy (1985). All panelists were regular consumers of cookies, water at room temperature was provided to rinse the mouth between evaluations.

\subsection{Statistical analysis}

All data were subjected to statistical analysis using Analysis of Variance (ANOVA). The means were then separated with the use of Duncan's New Multiple Range Test (DNMRT) using the Statistical Package for the Social Sciences (SPSS) 20.0 software.

\section{Results and Discussion}

\subsection{Functional properties of wheat, unripe plantain and fluted pumpkin seed composite flour}

Table 2 shows the functional properties of composite flour of wheat and unripe plantain fortified with germinated pumpkin seed flour. Composite flour had significant $(\mathrm{p}<0.05)$ reduction on the bulk density when compared with sample E. It ranged from 0.84-0.90 g/ml. Sample A had the highest value while the lowest value was observed in sample D. Decrease in bulk density of the composite flour could be attributed to decrease in carbohydrate with increase in sprouted pumpkin seed flour addition. The result agrees with Adelekan et al. (2013) whose value ranged from $0.62-0.90 \mathrm{~g} / \mathrm{ml}$ for trifoliate yam and pumpkin seed flour blends. The low values of bulk density for composite flour make it suitable for high nutrient density formulations of foods (Tumwine et al., 2018). The swelling capacity of composite flour ranged from $1.10 \mathrm{~g} / \mathrm{ml}$ in sample A to $1.27 \mathrm{~g} / \mathrm{ml}$ in sample D while sample E had $1.20 \mathrm{~g} / \mathrm{ml}$. The swelling index represents the water absorption of granules during heating (Adebowale et al., 2012). The swelling index in the composite flour was affected by the pumpkin seed flour addition which has considerable amount of protein and oil. The result is comparable with Bello et al. (2020) whose value ranged from 1.13-1.24 $\mathrm{g} / \mathrm{ml}$ for sprouted sorghum, pigeon pea and orange fleshed sweet potato flour blends. Water absorption capacity (WAC) of the composite flour ranged from 0.50-0.90 g/g in samples A to D, respectively. Samples B and C were not significantly $(\mathrm{p}>0.05)$ different. WAC is very vital in product processing as it affects its baking quality, viscosity and consistency of the products. Increase in WAC may be attributed to the low protein and high carbohydrate contents in the composite flour which agrees with the findings of Ohizua et al. (2016) and Bello et al. (2017). Oil absorption capacity ranged from $0.09 \mathrm{~g} / \mathrm{g}$ (sample A) to $1.07 \mathrm{~g} / \mathrm{g}$ (sample D) with sample samples $\mathrm{C}$ and D not significantly $(\mathrm{p}>0.05)$ different from sample E $(1.11 \mathrm{~g} / \mathrm{g})$. Similar findings were observed by Meka et al. (2019) for yellow maize, soybeans, and jackfruit seed composite flour. Gelatinization temperature (GT) decreased significantly and ranged from $75.00{ }^{\circ} \mathrm{C}$ in sample $\mathrm{D}$ to $81.00^{\circ} \mathrm{C}$ in sample A while sample $\mathrm{E}$ had the highest GT of $84.00{ }^{\circ} \mathrm{C}$. The lowest GT observed in sample D showed that composite flour took less time to gelatinized due to the increased in sprouted pumpkin seed flour. Variation in the gelation characteristics of composite flours could be attributed to the relative ratio of protein, carbohydrates and lipids that make up the flours and the interaction between such components (Iwe et al., 2016). There was no significant ( $\mathrm{p}>0.05)$ effect on the 
emulsification capacity of the composite flour when compared with the control. Protein being the surface active agents can form and stabilize the emulsion by creating electrostatic repulsion on oil droplet surface (Kaushal et al., 2012). Increasing emulsification and fat binding during processing are primary functional properties of protein. The result is lower than the result obtained by Ajani et al. (2016) whose value ranged from 10.05-18.86\% for composite of wheat and breadfruit.

Table 2. Functional properties of wheat, unripe plantain and fluted pumpkin seed composite flour

\begin{tabular}{ccccccc}
\hline Sample & $\begin{array}{c}\text { Bulk } \\
\text { density } \\
(\mathrm{g} / \mathrm{ml})\end{array}$ & $\begin{array}{c}\text { Swelling } \\
\text { capacity } \\
(\mathrm{g} / \mathrm{ml})\end{array}$ & $\begin{array}{c}\text { Water } \\
\text { absorption } \\
\text { capacity } \\
(\mathrm{g} / \mathrm{g})\end{array}$ & $\begin{array}{c}\text { Oil } \\
\text { absorption } \\
\text { capacity } \\
(\mathrm{g} / \mathrm{g})\end{array}$ & $\begin{array}{c}\text { Gelatinizatio } \\
\mathrm{n} \text { temp. }\left({ }^{\circ} \mathrm{C}\right)\end{array}$ & $\begin{array}{c}\text { Emulsificatio } \\
\mathrm{n} \text { capacity } \\
(\mathrm{g} / \mathrm{ml})\end{array}$ \\
\hline $\mathrm{A}(90: 5: 5)$ & $0.90^{\mathrm{ab}} \pm 0.03$ & $1.10^{\mathrm{c}} \pm 0.03$ & $0.50^{\mathrm{d}} \pm 0.00$ & $0.09^{\mathrm{c}} \pm 0.00$ & $81.00^{\mathrm{b}} \pm 1.00$ & $0.86^{\mathrm{a}} \pm 0.00$ \\
$\mathrm{~B}(85: 5: 10)$ & $0.86^{\mathrm{bc}^{\mathrm{c}} \pm 0.05}$ & $1.21^{\mathrm{a}} \pm 0.03$ & $0.80^{\mathrm{b}} \pm 0.00$ & $0.77^{\mathrm{b}} \pm 0.20$ & $79.00^{\mathrm{c}} \pm 1.00$ & $0.87^{\mathrm{a}} \pm 0.00$ \\
$\mathrm{C}(80: 5: 15)$ & $0.85^{\mathrm{bc}} \pm 0.02$ & $1.22^{\mathrm{b}} \pm 0.03$ & $0.80^{\mathrm{b}} \pm 0.00$ & $1.07^{\mathrm{a}} \pm 0.00$ & $77.00^{\mathrm{d}} \pm 1.00$ & $0.89^{\mathrm{a}} \pm 0.07$ \\
$\mathrm{D}(75: 5: 20)$ & $0.84^{\mathrm{c}} \pm 0.01$ & $1.27^{\mathrm{a}} \pm 0.00$ & $0.90^{\mathrm{a}} \pm 0.10$ & $1.13^{\mathrm{a}} \pm 0.21$ & $75.00^{\mathrm{e}} \pm 1.00$ & $0.85^{\mathrm{a}} \pm 0.02$ \\
$\mathrm{E}(100: 0: 0)$ & $0.91^{\mathrm{a}} \pm 0.01$ & $1.20^{\mathrm{b}} \pm 0.00$ & $0.70^{\mathrm{c}} \pm 0.00$ & $1.11^{\mathrm{a}} \pm 0.05$ & $84.00^{\mathrm{a}} \pm 1.00$ & $0.89^{\mathrm{a}} \pm 0.04$ \\
\hline
\end{tabular}

Values are means \pm SD of triplicate determinations. Means in the same column with different superscript are significantly $(\mathrm{p}<0.05)$ different. $\mathrm{W}=$ Wheat flour, $\mathrm{P}=$ Unripe plantain flour, $\mathrm{F}=$ Fluted pumpkin seed flour

\subsection{Physical properties of wheat, unripe plantain and fluted pumpkin seed composite flour cookies}

The result of the physical properties of cookies produced from wheat and unripe plantain composite flour fortified with germinated pumpkin seed flour is shown in Table 3. Fortification of wheat flour and unripe plantain flour with germinated pumpkin seed flour had a significant $(\mathrm{p}<0.05)$ increased on the weight of the cookies whose value ranged from 15.08-19.29 $\mathrm{g}$ for samples A and D, respectively, while sample E had $15.99 \mathrm{~g}$. The increase is an indication of the binding properties of the flour and of the texture of the cookies. This increase in weight may be as a result of increase in germinated pumpkin seed flour. The thickness of the cookies ranged from $0.89-1.17 \mathrm{~cm}$ while the sample E having the value of $1.04 \mathrm{~cm}$. The diameter of the cookies ranged from $1.00-1.15 \mathrm{~cm}$ with sample $C$ having the highest diameter and was not significantly $(\mathrm{p}>0.05)$ different from the sample $\mathrm{E}(1.01 \mathrm{~cm})$. The diameter and thickness of cookies increased with the addition of germinated pumpkin seed flour. There was no significant ( $p>0.05$ ) difference in spread ratio of all the cookies. It ranged from 0.95 (sample D) to 0.99 (sample B). The addition of fluted pumpkin seed flour had no significant ( $p>0.05$ ) effect on the cookies' spread ratio. AbuSalem and Abou-Arab (2011) also concluded that there was increase in diameter and thickness of cookies up to incorporation of $15 \%$ Bambara groundnut flour with no change in spread ratio.

Table 3. Physical properties of fortified cookies

\begin{tabular}{ccccc}
\hline Sample (W:P:F) & Weight $(\mathrm{g})$ & Thickness $(\mathrm{cm})$ & Diameter $(\mathrm{cm})$ & Spread ratio \\
\hline A $(90: 5: 5)$ & $15.08^{\mathrm{c}} \pm 0.77$ & $0.89^{\mathrm{c}} \pm 0.21$ & $0.86^{\mathrm{d}} \pm 0.02$ & $0.96^{\mathrm{a}} \pm 0.03$ \\
B (85:5:10) & $16.24^{\mathrm{bc}} \pm 0.19$ & $1.11^{\mathrm{b}} \pm 0.00$ & $1.10^{\mathrm{b}} \pm 0.00$ & $0.99^{\mathrm{a}} \pm 0.00$ \\
C (80:5:15) & $16.87^{\mathrm{b}} \pm 0.58$ & $1.17^{\mathrm{a}} \pm 0.09$ & $1.15^{\mathrm{a}} \pm 0.08$ & $0.98^{\mathrm{a}} \pm 0.01$ \\
D (75:5:20) & $19.29^{\mathrm{a}} \pm 1.48$ & $1.06^{\mathrm{b}} \pm 0.74$ & $1.00^{\mathrm{c}} \pm 0.43$ & $0.95^{\mathrm{a}} \pm 0.06$ \\
E $(100: 0: 0)$ & $15.99^{\mathrm{bc}} \pm 0.27$ & $1.04^{\mathrm{b}} \pm 0.09$ & $1.01^{\mathrm{c}} \pm 0.01$ & $0.97^{\mathrm{a}} \pm 0.02$ \\
\hline
\end{tabular}

Values are means \pm SD of triplicate determinations. Means in the same column with different superscript are significantly $(\mathrm{p}<0.05)$ different. $\mathrm{W}=$ Wheat flour, $\mathrm{P}=$ Unripe plantain flour, $\mathrm{F}=$ Fluted pumpkin seed flour

\subsection{Proximate composition of wheat, unripe plantain and fluted pumpkin seed composite flour cookies}

The result of the proximate composition of the cookies produced from composite of wheat and unripe plantain flour fortified with germinated pumpkin seed flour is presented in Table 4. Moisture content of fortified cookies ranged from 3.43-4.85\% for samples C and A, respectively with sample $\mathrm{E}$ having the value of 3.97\%. Moisture content in excess of $14 \%$ facilitates the growth of microorganism, which in turn causes spoilage and low nutritional qualities of the food products (Dabel et al., 2016), therefore the lower the moisture content of a sample, the more its storability. The moisture content of the samples was significantly low and would promote long storage ability of the product. Fortified cookies resulted in significant $(\mathrm{p}<0.05)$ increased in crude protein content whose value ranged from $8.81 \%$ (sample A) to $13.62 \%$ (sample D) while sample E gave the least value of $8.41 \%$. The higher protein content in germinated pumpkin seed flour relative to unripe plantain and wheat flours could have been responsible for the observed higher protein content in fortified cookies. Similar results have been reported by Ukeyima et al. (2019) for wheat, soy and carrot flour blends. The result showed that the cookies could be used to address the protein-energy malnutrition prevalence in most of our communities. Crude lipid content of the fortified cookies increased significantly $(\mathrm{p}<0.05$ ) at each level of fortification from $19.84 \%$ (sample A) to $22.67 \%$ (sample D). Fortified cookies had higher value than the control $(18.73 \%)$. The values obtained agrees with the result of 
Barber and Obinna-Echem (2016) for wheat-African walnut cookies. Fat plays a major role in determining the shelf life of foods. The ash content of the fortified cookies ranged from $2.59-2.96 \%$ for samples A to D, respectively, with the lowest value $(2.55 \%)$ found in sample E. Ash content is an indication of mineral content; hence samples with higher ash content are expected to have a relatively higher mineral content. The crude fibre of fortified cookies ranged from $2.10 \%$ in sample A to $2.33 \%$ in sample $\mathrm{C}$. The value $(1.56 \%)$ obtained for control was significantly $(\mathrm{p}<0.05)$ lower than the formulated cookies. The crude fibre content of the cookies increased steadily with increased in fortification. The values are higher that the finding of Chopra et al. (2018) for quinoa, sweet potato and wheat composite flour cookies. Fortified cookies resulted in a significant $(\mathrm{p}<0.05)$ reduction in the carbohydrate content from $61.81 \%$ in sample A to $54.93 \%$ in sample D, the control sample exhibited the highest value of $64.78 \%$. Similar trend was reported by Almasodi (2018) for some bakery products containing ginger powder.

Table 4. Proximate composition (\%) of wheat, plantain and pumpkin seed fortified cookies

\begin{tabular}{ccccccc}
\hline $\begin{array}{c}\text { Sample } \\
\text { (W:P:F) }\end{array}$ & Moisture & Crude protein & Crude fat & Ash & Crude fibre & \multirow{2}{*}{ Carbohydrate } \\
\hline A (90:5:5) & $4.85^{\mathrm{a}} \pm 0.14$ & $8.81^{\mathrm{d}} \pm 0.01$ & $19.84^{\mathrm{d}} \pm 0.08$ & $2.59^{\mathrm{b}} \pm 0.01$ & $2.10^{\mathrm{b}} \pm 0.02$ & $61.81^{\mathrm{a}} \pm 0.05$ \\
$\mathrm{~B}(85: 5: 10)$ & $3.83^{\mathrm{b}} \pm 0.04$ & $9.29^{\mathrm{c}} \pm 0.05$ & $20.60^{\mathrm{c}} \pm 0.07$ & $2.91^{\mathrm{a}} \pm 0.04$ & $2.12^{\mathrm{b}} \pm 0.02$ & $61.25 \pm 0.13$ \\
C (80:5:15) & $3.43^{\mathrm{c}} \pm 0.04$ & $11.17^{\mathrm{b}} \pm 0.28$ & $21.44^{\mathrm{b}} \pm 0.01$ & $2.93^{\mathrm{a}} \pm 0.00$ & $2.33^{\mathrm{a}} \pm 0.05$ & $58.70^{\mathrm{d}} \pm 0.10$ \\
D (75:5:20) & $3.58^{\mathrm{c}} \pm 0.11$ & $13.62^{\mathrm{a}} \pm 0.13$ & $22.67^{\mathrm{a}} \pm 0.08$ & $2.96^{\mathrm{a}} \pm 0.05$ & $2.24^{\mathrm{a}} \pm 0.03$ & $54.93^{\mathrm{e}} \pm 0.19$ \\
E (100:0:0) & $3.97^{\mathrm{b}} \pm 0.04$ & $8.41^{\mathrm{e}} \pm 0.01$ & $18.73^{\mathrm{e}} \pm 0.03$ & $2.55^{\mathrm{b}} \pm 0.02$ & $1.56^{\mathrm{c}} \pm 0.05$ & $64.78^{\mathrm{a}} \pm 0.05$ \\
\hline
\end{tabular}

Values are means \pm SD of triplicate determinations. Means in the same column with different superscript are significantly $(\mathrm{p}<0.05)$ different. $\mathrm{W}=$ Wheat flour, $\mathrm{P}=$ Unripe plantain flour, $\mathrm{F}=$ Fluted pumpkin seed flour

3.4 Anti-nutritional composition of wheat, unripe plantain and fluted pumpkin seed composite flour cookies The result of the antinutritional composition of cookies produced from composite of wheat flour and unripe plantain flour fortified with germinated pumpkin seed flour is shown in Table 5. Fortified cookies had significant $(\mathrm{p}<0.05)$ increase in the HCN content when compared with control. It ranged from $1.21 \mathrm{mg} / 100 \mathrm{~g}$ (sample A) to $2.80 \mathrm{mg} / 100 \mathrm{~g}$ (sample D), while the control sample had the lowest value of $0.98 \mathrm{mg} / 100 \mathrm{~g}$. According to BetancurAncona et al. (2008), the HCN level in fortified cookies was within the acceptable range for human consumption. He also stated that only plants with more than $200 \mathrm{mg}$ of $\mathrm{HCN}$ equivalent per $100 \mathrm{mg}$ fresh weight are considered dangerous. Fortification of wheat flour with unripe plantain and germinated pumpkin seed flour had a significant $(\mathrm{p}<0.05)$ increase in the tannin content of cookies whose value ranged from 2.31-5.36 mg/100g in samples A and $\mathrm{D}$, respectively. Sample E was found to have the lowest value $(2.10 \mathrm{mg} / 100 \mathrm{~g})$. Tannin is known to bind protein including digestive enzymes leading to poor protein digestibility. Ifie and Emeruwa (2011) stated that the lethal point of tannin is $90 \mathrm{mg} / 100 \mathrm{~g}$. The lower tannin content in the cookies made it safe for consumption according to its lethal point. Fortified cookies had the highest oxalate value when compared with the control sample, it values ranged from $235.00 \mathrm{mg} / 100 \mathrm{~g}$ (sample A) to $289.99 \mathrm{mg} / 100 \mathrm{~g}$ (sample D), while the control exhibited the lowest value of $124.26 \mathrm{mg} / 100 \mathrm{~g}$. High oxalate diet can increase the risk of renal calcium absorption and has been implicated as a source of kidney stones. The higher level of oxalate obtained in the fortified cookies corroborates with the finding of Bello et al. (2018) whose values ranged from 243.40-385.36 mg/100g for yellow yam, plantain and pumpkin seed flour blends cookies.

Table 5. Anti-nutritional (mg/100g) composition of fortified cookies

\begin{tabular}{cccccc}
\hline Sample (W:P:F) & HCN & Tannin & Oxalate & Phytate & Saponin \\
\hline A (90:5:5) & $1.21^{\mathrm{d}} \pm 0.02$ & $2.31^{\mathrm{d}} \pm 0.12$ & $235.00^{\mathrm{d}} \pm 0.00$ & $17.34^{\mathrm{a}} \pm 0.00$ & $10.14^{\mathrm{a}} \pm 0.01$ \\
B (85:5:10) & $1.38^{\mathrm{c}} \pm 0.01$ & $3.65^{\mathrm{c}} \pm 0.02$ & $254.81^{\mathrm{c}} \pm 0.01$ & $17.14^{\mathrm{a}} \pm 0.01$ & $5.02^{\mathrm{e}} \pm 0.01$ \\
C (80:5:15) & $2.65^{\mathrm{b}} \pm 0.02$ & $5.28^{\mathrm{b}} \pm 0.01$ & $268.77^{\mathrm{b}} \pm 0.00$ & $14.99^{\mathrm{c}} \pm 0.00$ & $6.10^{\mathrm{c}} \pm 1.15$ \\
D $(75: 5: 20)$ & $2.80^{\mathrm{a}} \pm 0.00$ & $5.36^{\mathrm{a}} \pm 0.00$ & $289.99^{\mathrm{a}} \pm 0.00$ & $13.20^{\mathrm{d}} \pm 0.00$ & $5.10^{\mathrm{d}} \pm 0.01$ \\
E $(100: 0: 0)$ & $0.98^{\mathrm{e}} \pm 0.01$ & $2.10^{\mathrm{e}} \pm 0.00$ & $124.26^{\mathrm{e}} \pm 0.02$ & $16.63^{\mathrm{b}} \pm 0.03$ & $7.15^{\mathrm{b}} \pm 0.01$
\end{tabular}

Values are means \pm SD of triplicate determinations. Means in the same column with different superscript are significantly $(\mathrm{p}<0.05)$ different. $\mathrm{W}=$ Wheat flour, $\mathrm{P}=$ Unripe plantain flour, $\mathrm{F}=$ Fluted pumpkin seed flour, $\mathrm{HCN}=$ Hydrogen cyanide

The fortification of wheat flour with unripe plantain and germinated pumpkin seed flour had a significant $(p<0.05)$ effect on the phytate content of the cookies whose value ranged from $13.20 \mathrm{mg} / 100 \mathrm{~g}$ in sample $\mathrm{D}$ to $17.14 \mathrm{mg} / 100 \mathrm{~g}$ (Sample B), while sample E had $16.63 \mathrm{mg} / 100 \mathrm{~g}$. Lethal point of phytate is $25 \mathrm{mg} / 100 \mathrm{~g}$ according to Nagel (2010). Phytate binds some essential mineral nutrients in the digestive tract and can result in mineral deficiencies. The fortification of wheat flour and unripe plantain with germinated pumpkin seed flour had a significant $(\mathrm{p}<0.05)$ increase in the saponin content of the cookies whose values ranged from $5.02-10.14 \mathrm{mg} / 100 \mathrm{~g}$ in sample B and A, respectively while sample $E$ had the value of $7.15 \mathrm{mg} / 100 \mathrm{~g}$. 


\subsection{Sensory scores of wheat, unripe plantain and fluted pumpkin seed composite flour cookies}

The sensory score of cookies produced from composite of wheat and unripe plantain composite flour fortified with germinated pumpkin seed flour is shown in Table 6. Fortified samples had the lowest rating scores in all the attributes evaluated when compared with the control. It ranged from 6.30-7.35, 6.45-7.30, 2.05-6.30 and 6.20-6.85 for aroma, appearance, taste and texture, respectively while the control had 7.45, 7.20, 7.45 and 6.75 for aroma, appearance, taste and texture, respectively. Reduction in flavour and taste scores in samples B, C and D may be caused by increased in polyphenol which give a bitter taste in these samples. The finding is in agreement with the Lesschaeve and Nobel (2005) who reported that the bitter tastes might be caused by increased in polyphenol. Control (100\% wheat flour cookies) was found to be generally accepted by the panelist followed by sample A $(90 \%$ wheat flour, 5\% unripe plantain and 5\% fluted pumpkin seed composite flour cookies).

Table 6: Sensory evaluation of fortified cookies

\begin{tabular}{cccccc}
\hline Sample (W:P:F) & Aroma & Appearance & Taste & Texture & $\begin{array}{c}\text { General } \\
\text { Acceptability }\end{array}$ \\
\hline A $(90: 5: 5)$ & $7.35^{\mathrm{a}} \pm 0.99$ & $7.05^{\mathrm{ab}} \pm 1.15$ & $6.30^{\mathrm{b}} \pm 1.53$ & $6.85^{\mathrm{a}} \pm 1.66$ & $6.95^{\mathrm{b}} \pm 1.32$ \\
B (85:5:10) & $6.90^{\mathrm{a}} \pm 1.41$ & $6.45^{\mathrm{c}} \pm 1.15$ & $4.70^{\mathrm{c}} \pm 1.59$ & $6.30^{\mathrm{a}} \pm 1.42$ & $5.05^{\mathrm{c}} \pm 1.61$ \\
C (80:5:15) & $6.60^{\mathrm{bc}} \pm 1.47$ & $7.05^{\mathrm{ab}} \pm 0.69$ & $3.55^{\mathrm{d}} \pm 1.67$ & $6.20^{\mathrm{a}} \pm 1.51$ & $4.45^{\mathrm{d}} \pm 1.90$ \\
D (75:5:20) & $6.30^{\mathrm{c}} \pm 1.13$ & $7.30^{\mathrm{a}} \pm 0.86$ & $2.05^{\mathrm{e}} \pm 0.94$ & $6.60^{\mathrm{a}} \pm 1.09$ & $2.65^{\mathrm{e}} \pm 1.67$ \\
E (100:0:0) & $7.45^{\mathrm{a}} \pm 0.99$ & $7.20^{\mathrm{a}} \pm 0.95$ & $7.45^{\mathrm{a}} \pm 0.99$ & $6.75^{\mathrm{a}} \pm 1.85$ & $7.75^{\mathrm{a}} \pm 0.85$ \\
\hline
\end{tabular}

Values are means \pm SD of triplicate determinations. Means in the same column with different superscript are significantly $(\mathrm{p}<0.05)$ different. $\mathrm{W}=$ Wheat flour, $\mathrm{P}=$ Unripe plantain flour, $\mathrm{F}=$ Fluted pumpkin seed flour

\subsection{Conclusion}

This work shows the composite flour of wheat, unripe plantain and germinated pumpkin seed flour as important ingredient in food formulation as increase in water absorption and swelling capacities were observed when compared with control $(100 \%$ wheat flour). It was also observed that fortified cookies had similar physical properties with the control in term of thickness, diameter and spread ratio. Increase in crude protein, crude fat, ash and high crude fibre contents were observed in the fortified cookies and this suggests that cookies could help reduce protein-energy malnutrition. The anti-nutrient levels in this study were lower than the lethal points which proved that the product is safe and good for consumption. Highest rating scores were recorded for control in all the attributes evaluated including general acceptability followed by sample A with the level of 5\% pumpkin seed flour addition. The production and consumption of fortified cookies could be improved by adopting processing methods that further reduce the effect of bitter taste in pumpkin seed which would encouraged its uses in snacks production.

\section{References}

Abbey, B. W. and Ibeh, G. O. (1988). Functional properties of raw and heat processed cowpea (Vigna unguiculata) flour. Journal of Food Science, 53(6):1178-1188.

Abu-Salem, F. M. and Abou-Arab, A. A. (2011). Effect of supplementation of Bambara groundnut (Vigna subterranean L.) flour on the quality of biscuits. African Journal of Food Science, 5(7): 376-383.

Adebowale, A. A., Adegoke, M. T., Sanni, S. A., Adegunwa, M. O. and Fetuga, G. O. (2012). Functional properties and biscuit making potentials of sorghum-wheat flour composite. American Journal of Food Technology, 7(6): 372-379.

Adelekan, A. O., Arisa, N. U., Adediran A. and Racheal, O. F. (2013). Effect of enrichment of trifoliate yam flour with pumpkin seeds flour on the pasting characteristics and the acceptability of its product. Journal Food Processing and Technology, 4:283.

Adewole, M. B. and Duruji, R. W. (2010). Quality assessment of plantain (Musa paradisiaca) as affected by different ripening method. African Journal of Biotechnology, 6(38).

Ajani, A. O., Fasoyiro, S .B., Arowora, K. A., Ajani, O. O., Popoola, C. A. and Zaka, K. O. (2016). Functional properties of composite flour made from wheat and breadfruit. Applied Tropical Agriculture, 21(2): 89-93.

Akusu, O. M., Kiin-Kabari, D. B. and Isah, E. M. (2019). Effects of processing methods on the nutrient composition and sensory attributes of cookies produced from wheat and sesame seed flour blends. International Journal of Nutrition Science and Food Technology, 5(5): 34-40.

Allen, S. E., Grimshaw, H. M., Parkinson, J. and Quarmby, C. (1974). Chemical analysis of ecological materials. Blackwell Scientific, Oxford.

Almasodi, A. G. S. (2018). Production and evaluation of some bakery products containing ginger powder. Journal of Food and Nutrition Research, 6(4): 205-215.

AOAC (2005). Official Methods of Analysis (18th edition). Association of Official Analytical Chemist, Washington DC, USA.

Arisa, N. N., Adelakan, A. O., Alamu, A. E. and Ogunfowora, E. J. (2013). The effect of pretreatment of plantain 
(Musa paradisiaca) flour on the pasting and sensory characteristics of biscuit. International Journal of Food and Nutrition Science, 2(1):10-23.

Barber, L. I. and Obinna-Echem, P. C. (2016). Nutrient composition, physical and sensory properties of wheatAfrican walnut cookies. Sky Journal of Food Science, 5(4): 24-30.

Bello, F. A., Akpan, E. E. and Ntukidem, V. E. (2020). Development and quality characteristics of cookies from sprouted sorghum, pigeon pea and orange fleshed sweet potato flour blends. European Journal of Nutrition \& Food Safety, 12(2): 11-21.

Bello, F. A., Ntukidem, O. J. and Oladeji, B.S. (2018). Assessment of chemical compositions, physical and sensory properties of biscuits produced from yellow yam, unripe plantain and pumpkin seed flour blends. International Journal of Food Science and Nutrition Engineering, 8(5): 119-126.

Bello, F. A., Udo, I. I. and Mbak, D. L. (2017). Proximate composition and functional properties of sprouted sorghum (Sorghum bicolor) and defatted fluted pumpkin seed (Telfairia occidentalis) flour blends. American Journal of Innovative Research and Applied Sciences, 5(4): 254-259.

Betancur-Ancona, D., Gallegos-Tintore, S., Ddelgado-Herrera, A., Perez- Flores, V., Ruelas, A. C. and Luis ChelGuerrero, L. (2008). Some physicochemical and anti-nutritional properties of raw flours and protein isolates from Mucuna pruriens (velvet bean) and Canavalia ensiformis (jack bean). International Journal of Food Science and Technology, 43: 816-823.

Bojňanská, T., Helena, F., Miriam, L. and Marian, T. (2012). Legumes - the alternative raw materials for bread production. Journal of Microbiology, Biotechnology and Food Sciences, 1: 876-886.

Chauhan, A., Saxena, D. C. and Singh, S. (2015). Total dietary fibre and antioxidant activity of gluten free cookies made from raw and germinated amaranth (Amaranthus spp.) flour. LWT - Food Science and Technology, 63: 939-945.

Chopra, N., Dhillon, B., Rani, R. and Singh, A. (2018). Physico-nutritional and sensory properties of cookies formulated with quinoa, sweet potato and wheat flour blends. Current Research in Nutrition and Food Science, 6(3): 798-806.

Dabels, N., Igbabul B. D., Amove, J. and Iorliam, B. (2016). Nutritional composition, physical and sensory properties of cookies from wheat, acha and mung bean composite flours. International Journal of Nutrition and Food Sciences, 5(6): 401-406.

Ehiagbonare, J. E. (2008). Conservation studies on Telfairia occidentalis Hook .F. A. indigenous plant used in enthnomedicinal treatment of anaemia in Nigeria. African. Journal of Agricultural Research, 3(1): 74-77.

Food and Agriculture Organization of the United Nations - FAO. (2013). FAOSTAT.

Hasmadi, M., Siti, F. A., Salwa, I., Matanjun, P., Abdul, H. M. and Rameli, A. S. (2014). The effect of seaweed composite flour on the textural properties of dough and bread. Journal of Applied Phycology, 26:1057-1062.

Hugo, L. F., Rooney, L. W. and Taylor, J. R. N. (2000). Malted sorghum as a functional ingredient in composite bread. Cereal Science, 79(4): 428-432.

Ifie, I. and Emeruwa, C. H. (2011). Nutritional and anti-nutritional characteristics of the larva of Oryctes monoceros. Agriculture Biology Journal of North America, 2(1):42-46.

Ihekoronye, I. A. and Ngoddy. O. P. (1985). Integrated Food Science and Technology for the Tropics. Macmillan Publishers Ltd (1985), pp. 180-189.

Inyang, U. E., Daniel, E.A. and Bello, F. A. (2018). Production and quality evaluation of functional biscuits from whole wheat flour supplemented with acha (fonio) and kidney bean flours. Asian Journal of Agriculture and Food Sciences, 6(6): 193-201.

Iwe, M. O., Onyeukwu, U. and Agiriga, A. N. (2016). Proximate, functional and pasting properties of FARO 44 rice, African yam bean and brown cowpea seeds composite flour. Cogent Food and Agricultural Journal, 2:5.

Jemziya, M. B and Mahendran, T. (2017). Physical quality characters of cookies produced from composite blends of wheat and sweet potato flour. Ruhuna Journal of Science, 8(1): 12-23.

Kaushal, P., Kumar, V. and Sharma, H. K. (2012). Comparative study of physico-chemical, functional, antinutritional and pasting properties of taro (Colocasia esculenta), rice (Oryza sativa), pigeon pea (Cajanus cajan) flour and their blends. Food Science and Technology, 48:59-68.

Kuku, U. I., Etti. U. J. and Ibironke, I. S. (2007). Processing of fluted pumpkin seeds, Telfairia occidentalis (hook f) as it affects growth performance and nutrient metabolism in rats. African Journal of Food, Agriculture, Nutrition and Development, 14(5): 922-2014.

Lesschaeve, I. and Noble, A. C. (2005). Polyphenols: factors influencing their sensory properties and their effects on food and beverage preferences. American Journal of Clinical Nutrition, 81(1): 330-335.

Makanjuola, R. N. (2013). The proximate composition and mineral contents of three plantain cultivars harvested at matured green level. International Journal of Innovations in Bio-Sciences, 3 (2): 23-26.

Meka, E., Igbabul, B. D. and Ikya, J. (2019). Chemical and functional properties of composite flours made from yellow maize, soybeans, and jackfruit seed. International Journal of Research and Innovation in Applied Science (IJRIAS), 4(11): 57-63. 
Mohammed, L. A. (2012). Dough rheology and bread quality of wheat-chickpea flour blends. Industrial Crops and Products, 36: 196-202.

Nagel, R. (2010). Living with phytic acid. Journal of Wine Traditions in Food, Farming and Healing Arts, Weston A. Price Foundation. http:/www.westonsprice.org/food-features/Living-with-phytic-acid.

Obinna-Echem, P. C. and Robinson, E. S. (2019). Proximate composition, physical and sensory properties of biscuits produced from blends of maize (Zea mays) and tigernut (Cyperus esculentus) flour. Sky Journal of Food Science, 7(2): 030-036.

Ogazi, P. O and Adeyemi, I. A. (1985). Pilot scale dehydration of plantain pulp for flour production using cabinet dryer. Nigeria Food Journal, 8: 74-77.

Ohizua, E. R., Adeola, A. A., Idowu, M. A., Sobukola, O. P., Afolabi, T.A., Ishola, R. O., Ayansina, S. O., Oyekale, T. O. and Falomo., A. (2017). Nutrient composition, functional, and pasting properties of unripe cooking banana, pigeon pea, and sweet potato flour blends. Food Science and Nutrition, 1-13.

Onwuka, G. I. (2005). Food Analysis and Instrumentation, Naphthal Print, Surulere, Lagos, Nigeria. pp. 133-139.

Topping, D. (2007). Cereal complex carbohydrates and their contribution to human health. Journal of Cereal Science, 46: 220-229.

Tumwine, G., Atukwase, A., Tumuhimbise, G. A., Tucungwirwe, F. and Linnemann, A. (2019). Production of nutrient-enhanced millet-based composite flour using skimmed milk powder and vegetables. Food Science and Nutrition, 7:22-34.

Ubbor, S. C. and Akobundu, E. N. T. (2009). Quality characteristics of cookies made from composite flours of watermelon seed, cassava and wheat. Pakistan Journal of Nutrition, 8: 1097-1102.

Ukeyima, M. T., Dendegh, T. A. and Okeke, P. C. (2019). Effect of carrot powder addition on the quality attributes of cookies produced from wheat and soy flour blends. Asian Food Science Journal, 10(3): 1-13.

Usman, G. O., Ameh, U. E., Alifa, O. N. and Babatunde, R. M. (2015). Proximate composition of biscuits produced from wheat flour and maize bran composite flour fortified with carrot extract. Journal of Nutrition and Food Sciences, 5.

Vijerathna, M. P. G., Wijesekara, L., Perera, R., Maralanda, S. M. T. A., Jayasinghe, M. and Wickramasinghe, I. (2019). Physico-chemical characterization of cookies supplemented with sugarcane bagasse fibres. Vidyodaya Journal of Science, 22(1): 29-39.

Wabali, V. C., Giami, S. Y., Kiin-Kabari, D. B. and Akusu, O. M. (2020). Physiochemical, anti-nutrient and invitro protein digestibility of biscuits produced from wheat, African walnut and moringa seed flour blends. Asian Food Science Journal, 14(1): 17-26.

Wheeler, E. L. and Ferrel, R. E. (1971). A method for phytic acid determination in wheat and wheat fractions. Cereal Chemistry, 48: 312-316. 